\title{
Loss of Natural Habitats: High-Altitude Vegetation, Pantanal
}

\author{
Perda de Habitats Naturais: Campos de Altitude, Pantanal \\ Perdida de Hábitats Naturales: Campos de Altitud, Pantanal
}

Received: 01/27/2022 | Reviewed: 01/31/2022 | Accept: 02/05/2022 | Published: 02/09/2022

\author{
Dhonatan Diego Pessi \\ ORCID: https://orcid.org/0000-0003-0781-785X \\ Universidade Federal de Mato Grosso do Sul, Brazil \\ E-mail: dhonatan.pessi@gmail.com \\ Marco Antonio Diodato \\ ORCID: https://orcid.org/0000-0002-9088-836X \\ Universidade Federal Rural do Semi Árido, Brazil \\ E-mail: diodato@ufersa.edu.br \\ Angélica Guerra \\ ORCID: https://orcid.org/0000-0001-6399-8507 \\ Instituto Homem Pantaneiro, Brazil \\ E-mail: angelicaguerra14@hotmail.com \\ Normandes Matos da Silva \\ ORCID: https://orcid.org/0000-0002-4631-9725 \\ Universidade Federal de Rondonópolis, Brazil \\ E-mail: normandes@ufr.edu.br \\ Alfredo Marcelo Grigio \\ ORCID: https://orcid.org/0000-0002-2094-9710 \\ Universidade do Estado do Rio Grande do Norte, Brazil \\ E-mail: alfredogrigio1970@gmail.com \\ Camila Leonardo Mioto \\ ORCID: https://orcid.org/0000-0002-6951-9527 \\ Universidade Federal de Rondonópolis, Brazil \\ E-mail: ea.mioto@gmail.com \\ Vinícius de Oliveira Ribeiro \\ ORCID: https://orcid.org/0000-0002-4373-1132 \\ Universidade Estadual de Mato Grosso do Sul, Brazil \\ E-mail: viniciusoribeiro@yahoo.com.br \\ Geraldo Alves Damasceno Junior \\ ORCID: https://orcid.org/0000-0002-4554-9369 \\ Universidade Federal de Mato Grosso do Sul, Brazil \\ E-mail: geraldodamasceno@gmail.com \\ Antonio Conceição Paranhos Filho \\ ORCID: https://orcid.org/0000-0002-9838-5337 \\ Universidade Federal de Mato Grosso do Sul, Brazil \\ E-mail: antonio.paranhos@ufms.br
}

\begin{abstract}
The objective of this study is to quantify the spatiotemporal variation of high-altitude grassland (Campos de Altitude) in two different study areas between 1985 and 2020. First, the types of vegetation present in both areas were classified using a false-color (Red, Green, Blue) composition, with the channels replaced by mid-infrared, near-infrared, red, respectively. Following the definition of vegetation classes and the creation of polygons over them, they were superimposed on the NDVI product (1985 and 2020) to obtain the maximum and minimum values of the index and to identify which value ranges each class would be in. Next, a multitemporal false-color composition was carried out with the modification of the Red channel by the NDVI 1985 product, the Green channel by the NDVI 2020 product and the Blue channel without any changes. The results show that the total area of Campos de Altitude decreased between 1985 and 2020 in both study areas, with area 1 losing 31.93\% and area 2 losing 35.12\%, whereas the vegetation of denser strata (arboreal) increased in its spatial distribution in both study areas, with area 2 gaining the most $(230 \%)$. There was a noticeable increase in arboreal vegetation in the two study areas during the years analyzed. The tendency for the fraction of arboreal vegetation cover to increase is in line with the decrease in Campos de Altitude vegetation, and this phenomenon may be related to environmental factors such as temperature variations, amount of rainfall, solar radiation, and soil composition.
\end{abstract}

Keywords: Alpine vegetation; Multi-temporal composition; Remote sensing; Spatiotemporal; Vegetation index. 


\section{Resumo}

O objetivo foi quantificar a variação espaço-temporal da vegetação Campos de Altitude em duas diferentes áreas de análise entre os anos de 1985 e 2020. Primeiro foi realizada a classificação dos tipos de vegetação presentes nas duas áreas, por meio de uma composição falsa-cor RGB (Red, Green, Blue) substituindo os canais respectivamente pelos MIR-NIR-R (Middle Infrared, Near Infrared, Red). Após definir as classes de vegetação e criar polígonos sobre elas, foram sobrepostas ao produto NDVI (1985 e 2020), visando obter os valores máximos e mínimos do índice e identificar em quais faixas de valores estariam cada classe. Na sequência realizou-se uma composição falsa-cor multitemporal com a modificação do canal Red pelo produto NDVI 1985, canal Green pelo produto NDVI 2020 e o canal Blue sem nenhuma alteração. Os resultados demonstram que a área total dos Campos de Altitude diminuiu entre 1985 e 2020 nas duas áreas de estudo, sendo que na área 1 sofreu uma redução de 31,93\% e na área 2 uma redução de $35,12 \%$, enquanto que a vegetação de estrato mais denso (arbórea) ocorreu absolutamente o oposto, aumentou em sua distribuição espacial para ambas as áreas de estudo, sendo mais significativo o ganho na área 2 (230\%). Houve um aumento perceptível de vegetação arbórea nas duas áreas de estudo durante os anos analisados. A tendência de aumento da fração da cobertura da vegetação arbórea está em consonância com a diminuição da vegetação Campos de Altitude e, esse fenômeno, pode ter relação com fatores ambientais, tais como variações na temperatura, quantidade de chuvas, radiação solar e composição do solo.

Palavras-chave: Composição multitemporal; Sensoriamento remoto; Vegetação alpina; Espaço-temporal; Índice de vegetação.

\section{Resumen}

El objetivo fue cuantificar la variación espacial y temporal de la vegetación de los Campos de Altitud en dos zonas de análisis distintas entre los años 1985 y 2020. En primer lugar se realizó la clasificación de los tipos de vegetación presentes en las dos zonas, mediante una falsa -composición de color RGB (Rojo, Verde, Azul) reemplazando los canales respectivamente por MIR-NIR-R (Middle Infrared, Near Infrared, Red). Luego de definir las clases de vegetación y crear polígonos sobre ellas, se superpusieron al producto NDVI (1985 y 2020), con el fin de obtener los valores máximos y mínimos del índice e identificar en qué rangos de valores estaría cada clase. Posteriormente se realizó una composición multitemporal en falso color con la modificación del canal Rojo por el producto NDVI de 1985, el canal Verde por el producto NDVI de 2020 y el canal Azul sin cambios. Los resultados muestran que la superficie total de Campos de Altitud disminuyó entre 1985 y 2020 en las dos zonas de estudio, habiendo en la zona 1 una reducción del 31,93\% y en la zona 2 una reducción del 35,12\%, mientras que el estrato de vegetación más densa (árbol) ocurrió exactamente lo contrario, aumentó en su distribución espacial para ambas áreas de estudio, siendo el aumento más significativo en el área 2 (230\%). Hubo un aumento notable en la vegetación arbórea en las dos áreas de estudio durante los años analizados. La tendencia a aumentar la fracción de cobertura arbórea está de acuerdo con la disminución de la vegetación de Campos de Altitud, y este fenómeno puede estar relacionado con factores ambientales, como variaciones de temperatura, cantidad de lluvia, radiación solar y composición del suelo.

Palabras clave: Composición multitemporal; Detección remota; Vegetación alpina; Espacio-temporal; Índice de vegetación.

\section{Introduction}

Native vegetation plays a key role in terrestrial ecosystems as it affects land cover, provides ecosystem services such as water availability and quality, stores and sequestrates carbon, contributes to climate regulation, controls erosion and sedimentation, and helps to maintain biodiversity (Newbold 2018, Jeong et al. 2011). However, the native vegetation of all ecosystems has changed dramatically, owing primarily to changes in land use and climate change. Alterations in land use, such as the conversion of natural areas to provide food, fiber, water, and shelter for the population, are the primary drivers of native vegetation loss (Foley et al. 2005). Climate change can also affect the pattern of distribution and growth of vegetation through precipitation, temperature, and radiation, which can alter available energy and water, both of which are essential for plant growth, impacting the process of carbon accumulation in the water cycle as well as the decomposition and conversion of organic carbon (Linscheid et al. 2020; Tai et al. 2020; Pan et al. 2018).

Numerous studies in various regions, such as the Tibetan Plateau, have shown that vegetation changes exhibit spatial and temporal heterogeneity, and the effects of climate change on vegetation reflect its spatial and temporal variation (Tai et al. 2020; Zhang et al. 2019). Exploring the spatial and temporal pattern of vegetation and discussing the role of climate factors has been one of the main topics of current global change research, with important theoretical and practical implications for assessing the quality of terrestrial ecosystems and regulating ecological vegetation processes (Tai et al. 2020; Wamelink et al. 
2018; Mu et al. 2020).

The change in the spatial and temporal distribution of vegetation is also an important indicator of the dynamic responses of ecosystems to climate change (Zhang et al. 2019; Jeong et al. 2011). As a result, research on the spatiotemporal distribution of vegetation is relevant not only for improving the understanding of vegetation responses to climate change, but also for increasing the accuracy of predictions (Pouliot et al. 2009; Zhang et al. 2019).

In this context, mapping the distribution and composition of vegetation is a fundamental practice for assessing ecosystem dynamics and their response to climate change on a large scale. Traditional field surveys are frequently limited because they do not provide spatial and temporal coverage data due to significant water dynamics, complex types of coverage, and vast dimensions of the system (Han et al. 2015; Mu et al. 2020). Thus, several methods for obtaining the spatiotemporal distribution of vegetation using remote sensing images have been developed, as the first works used visual interpretation to discriminate and map types of coverage using compositions of true or false colors (Johnston \& Barson 1993).

The development of rule-based models, such as machine learning algorithms, has vastly improved classification accuracy over time (Mu et al. 2020; Hu et al. 2015; Chen et al. 2018). Supervised classification has been widely used in the differentiation of various plant phenology (Berberoglu et al. 2004; Han et al. 2015; Dronova et al. 2012). Another technique that has been employed in the spatiotemporal analysis of vegetation is the multi-temporal classification, the same used in the work by Peres et al. (2016) who, through false-color composition techniques of the RGB spectral bands of NDVI (Normalized Difference Vegetation Index) data, were able to generate information on areas that suffered phytomass reduction, which tend to red, as well as those that had an increase, which appear in green, and areas without changes in vegetation cover, which are visualized in yellow.

The Pantanal is the world's largest tropical floodplain; however, there are some isolated massifs in the middle of the Pantaneira plain, such as Urucum, with an elevation of 1,160 meters near the city of Corumbá, and Serra do Amolar. The biome is the most preserved in Brazil, with more than $85 \%$ of native vegetation (SOS PANTANAL et al. 2017), but it is also dependent on activities carried out in the Upper Paraguay Basin Plateau, which is undergoing rapid conversion of land use (Roque et al. 2016; Guerra et al. 2020). The region also experiences severe droughts as a result of climate change, which affects the biome's water regime (Marengo et al. 2021).

Serra do Amolar and Morraria do Urucum have a typical high-altitude vegetation cover known as Campos de Altitude (high-altitude grassland), which plays an important role in the regional ecological environment. The elevation gradient in Serra do Amolar results in distinct vertical distributions of climate and vegetation. The goal of this study is to quantify the spatiotemporal variation of the vegetation present in these two areas of analysis between 1985 and 2020, thus providing evidence of vegetation variation that may be linked to environmental or anthropogenic factors. Based on such analysis, it is possible to raise questions about what caused this vegetation to undergo modification over the years.

\section{Methodology}

\subsection{Study area}

The study area comprises two sample areas, namely Serra do Amolar and Maciço do Urucum, both inserted in the Pantanal sul-mato-grossense, in the municipality of Corumbá-MS (Figure 1). 
Figure 1 - Location of the two study areas, in a) Serra do Amolar, and in b) Morraria do Urucum, both inserted in the Pantanal context.

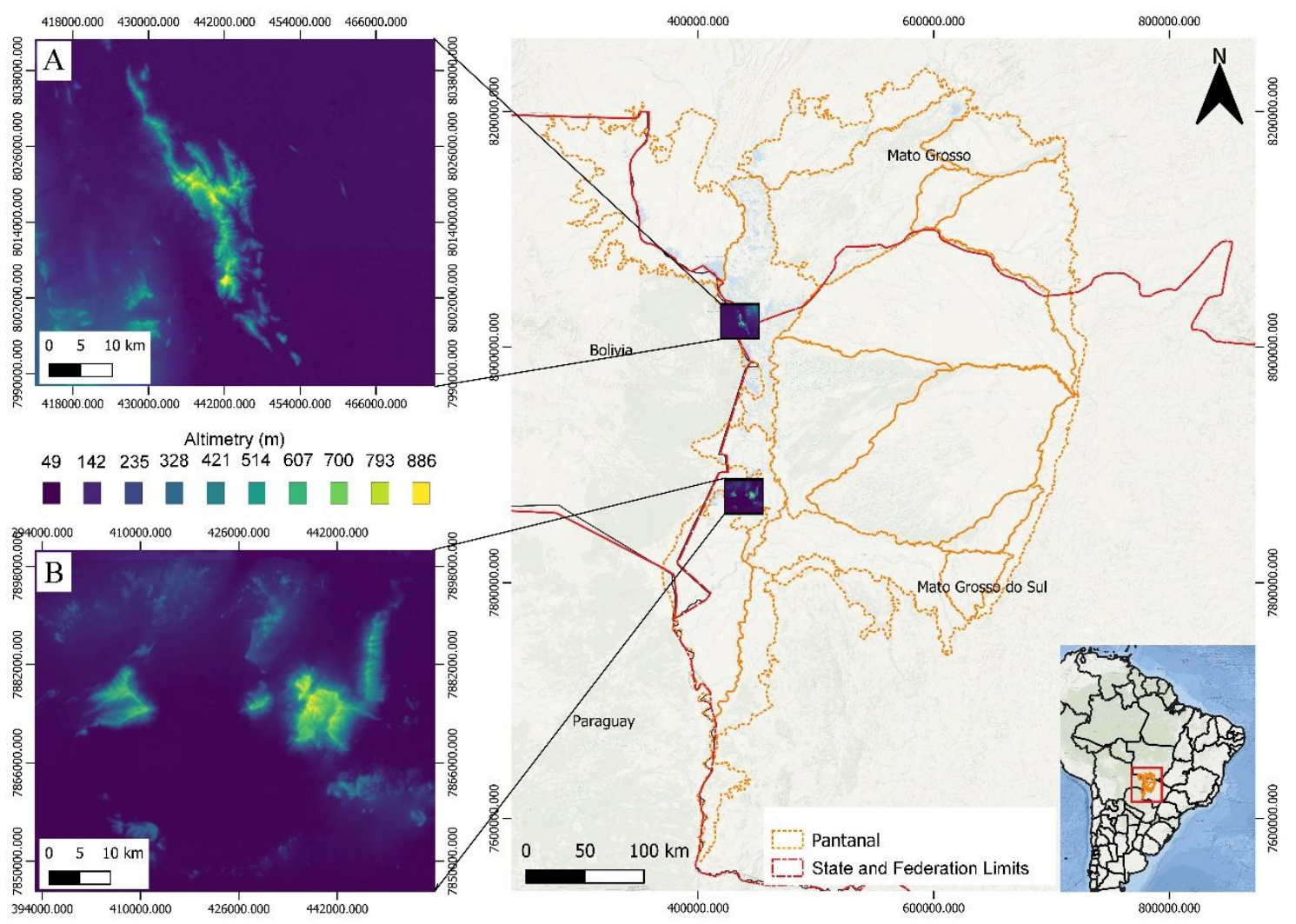

Source: Pantanal vector data: Mioto et al. (2012); Vector data of states and municipalities at: https://www.ibge.gov.br/geociencias/downloads-geociencias.html; UTM SIRGAS 2000, 21S coordinate system; Image data: TOPODATA available at: http://www.webmapit.com.br/inpe/topodata/.

Serra do Amolar is located in the Pantanal sub-region named Paraguay (Silva \& Abdon 1998; Mioto et al. 2012), because of the Paraguay River that borders the Serra, having peculiar characteristics of the region as it is a border area with the Bolivian Chaco and because of its presence. of large permanently flooded bays (Larcher et al. 2017; Junk et al. 2006), constituting a composition between the Pantanal plain and the Serra do Amolar, representing one of the greatest biological diversity assets in Brazil (IHP 2012). It is located $180 \mathrm{~km}$ from the municipality of Corumbá and has an extension of approximately $40 \mathrm{~km}$ along the border between Brazil and Bolivia (Larcher et al. 2017), with Pre-Cambrian geological formations, which exercise geological control over the flow of water of the Pantanal (Souza \& Souza 2010). Serra do Amolar has the highest point at around 1,000 meters of altitude, and in this area the vegetation is mainly formed by lowland ecosystems up to Campos de Altitude which, together, form a potentially important biological and geographic corridor (ECOTROPICA 2003, Larcher et al. 2017).

The Urucum massif is located near the urban area of Corumbá, formed by residual hills located on the southwestern edge of the Pantanal, having the highest points in the state of Mato Grosso do Sul, with altitudes above 1,000 meters (Urbanetz et al. 2012). The hills are surrounded by the Pantanal floodplain, a contact region of different phytogeographic provinces, such as the Amazon, Cerrado, Chaco and Southern Forests, in addition to being of special interest for conservation, with endemic species such as Aspilia grazielae in the fields of altitude and Gomphrena centrota in the lateritic benches (Pott et al. 2000 2011; Urbanetz et al. 2012).

It is worth noting that in Maciço do Urucum there is mining activity, as it has a large reserve of iron ore and manganese. These activities have been modifying the landscape of the morraria, putting the plant community and the stability 
of the land at risk.

\subsection{Reporting period, Landsat 8 and Landsat 5 images}

Landsat 8 (LANDSAT 2020) and Landsat 5 (LANDSAT 1985) images were used in this study, extension .TIF, both projected in the UTM SIRGAS 2000 Geographical Projection System, which was obtained for free from the website https://espa.cr.usgs.gov/index/. (US Department of the Interior US Geological Survey), which provides all spectral bands as well as pre-calculated vegetation indices. Both images received radiometric correction and treatments for better use and standardization of images, since we are working with different sensors (OLI and TM) which results in small differences in the spectral information of the images. Only the NDVI vegetation index was obtained for this study, along with the other products. Here, the years of analysis are 1985 to 2020, and the dates of the selected images were September 12, 1985 for Morraria do Urucum, August 27, 1985 for Serra do Amolar, and September 28, 2020 for both areas. The image dates correspond to Pantanal's dry season, when there is a greater contrast between phytophysiognomies and a smaller water surface (PERES et al. 2016).

\subsection{Classification of vegetation types}

To identify the vegetation types in the study area, a false-color RGB (Red, Green, Blue) composition was created in QGIS 3.10 (QGIS Development Team 2021), with the Red channels replaced by MIR (mid-infrared), the Green channels replaced by NIR (near-infrared), and the Blue channels replaced by R (red) (Figure 2). Table 1 shows the bands used and channels assigned to each satellite. 
Figure 2 - Modified false-color RGB composition for MIR-NIR-R bands for both areas of analysis, and two years of research (2020-1985). In Morraria do Urucum, Scene A is from 2020 (28/09/2020), and Scene B from 1985 (27/08/1985). In Serra do Amolar, Scene C is from 2020, and Scene D from 1985. The images were all taken during Pantanal's dry season. The difference in water volume between images C and D is the result of a severe drought which occurred in Pantanal in 2020.

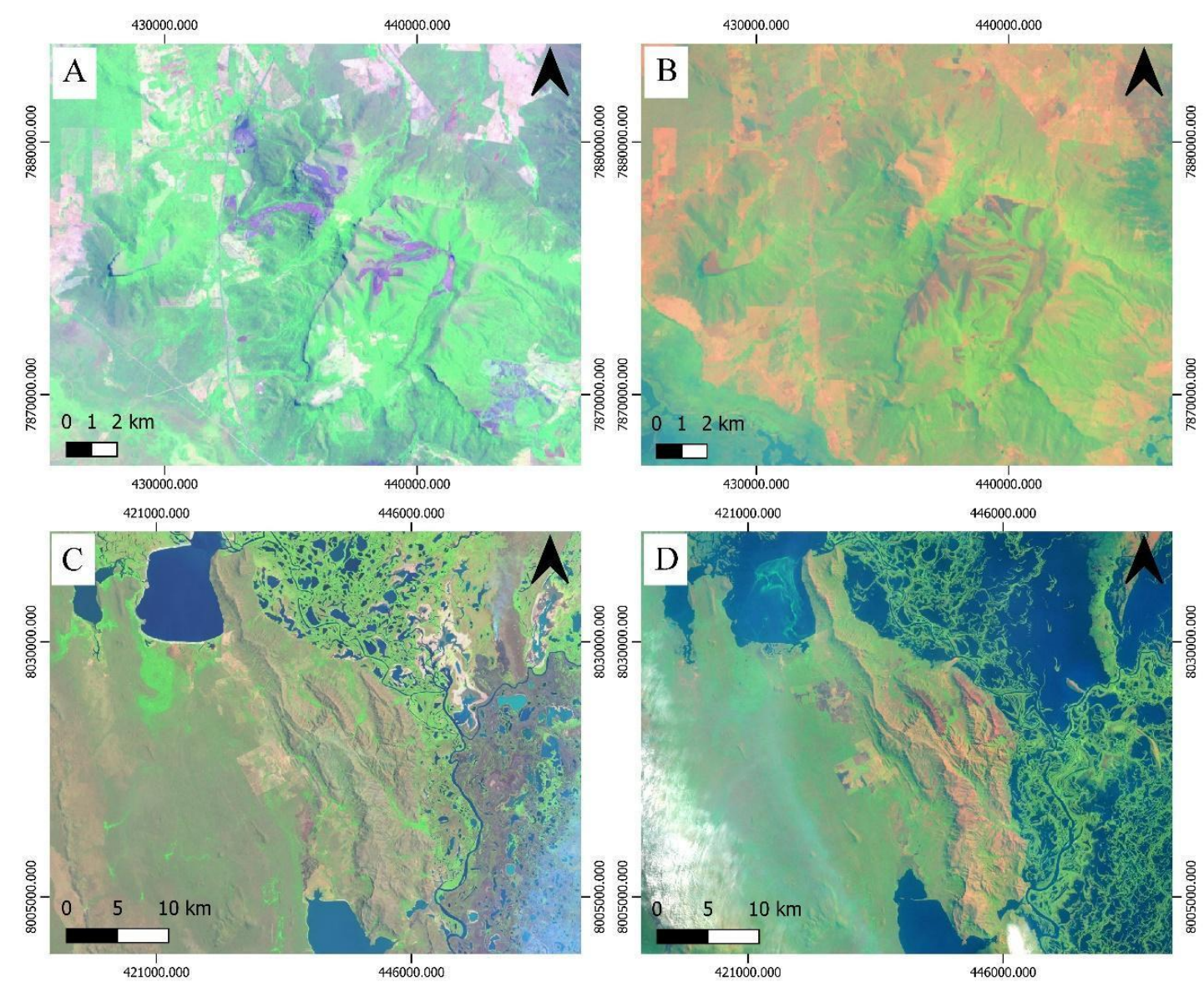

Source: Images from Landsat 8 (U.S. Department of the Interior U.S. Geological Survey, 2020).

Table 1 - Information on the spectral bands used in the study and their respective channels for each of the satellites employed in the analysis.

\begin{tabular}{ccccc}
\hline Satellite & Sensor & Spectral bands & Spectral Resolution & Spatial Resolution \\
\hline \multirow{2}{*}{ Landsat } & \multirow{2}{*}{ TM (Thematic Mapper) } & Red (B3) & $0.63-069 \mu \mathrm{m}$ & \\
5 & & Near-Infrared (B4) & $0.76-0.90 \mu \mathrm{m}$ & $30 \mathrm{~m}$ \\
& & Mid-Infrared (B5) & $1.55-1.75 \mu \mathrm{m}$ & \\
\hline \multirow{2}{*}{ Landsat } & \multirow{2}{*}{ OLI (Operational Land Imager) } & Red (B4) & $0.630-0.680 \mu \mathrm{m}$ & $30 \mathrm{~m}$ \\
& & Near-Infrared (B5) & $0.845-0.885 \mu \mathrm{m}$ & \\
\hline
\end{tabular}

Source: Authors.

This same composition was used in a study conducted in Pantanal by Peres et al. (2016), who differentiated the arboreal/shrubby and undergrowth classes using the same modified RGB composition mentioned in the preceding paragraph. Thus, we decided to apply it in the present study to carry out the analyses, as we intended to differentiate the same classes.

Following the composition procedure, it was possible to identify the areas with arboreal vegetation, grassy vegetation (Campos de Altitude, high-altitude grassland), and exposed soil for both study areas (Figure 3). 
Figure 3 - Identification of vegetation classes in the two areas of analysis. A corresponds to Morraria do Urucum; A1 grassy (Campos de Altitude), A2 arboreal/shrubby vegetation, A3 area with exposed soil (important to mention these areas so as not to confuse them with vegetation). B corresponds Serra do Amolar; B1 grassy (Campos de Altitude), B2 arboreal/shrubby vegetation.

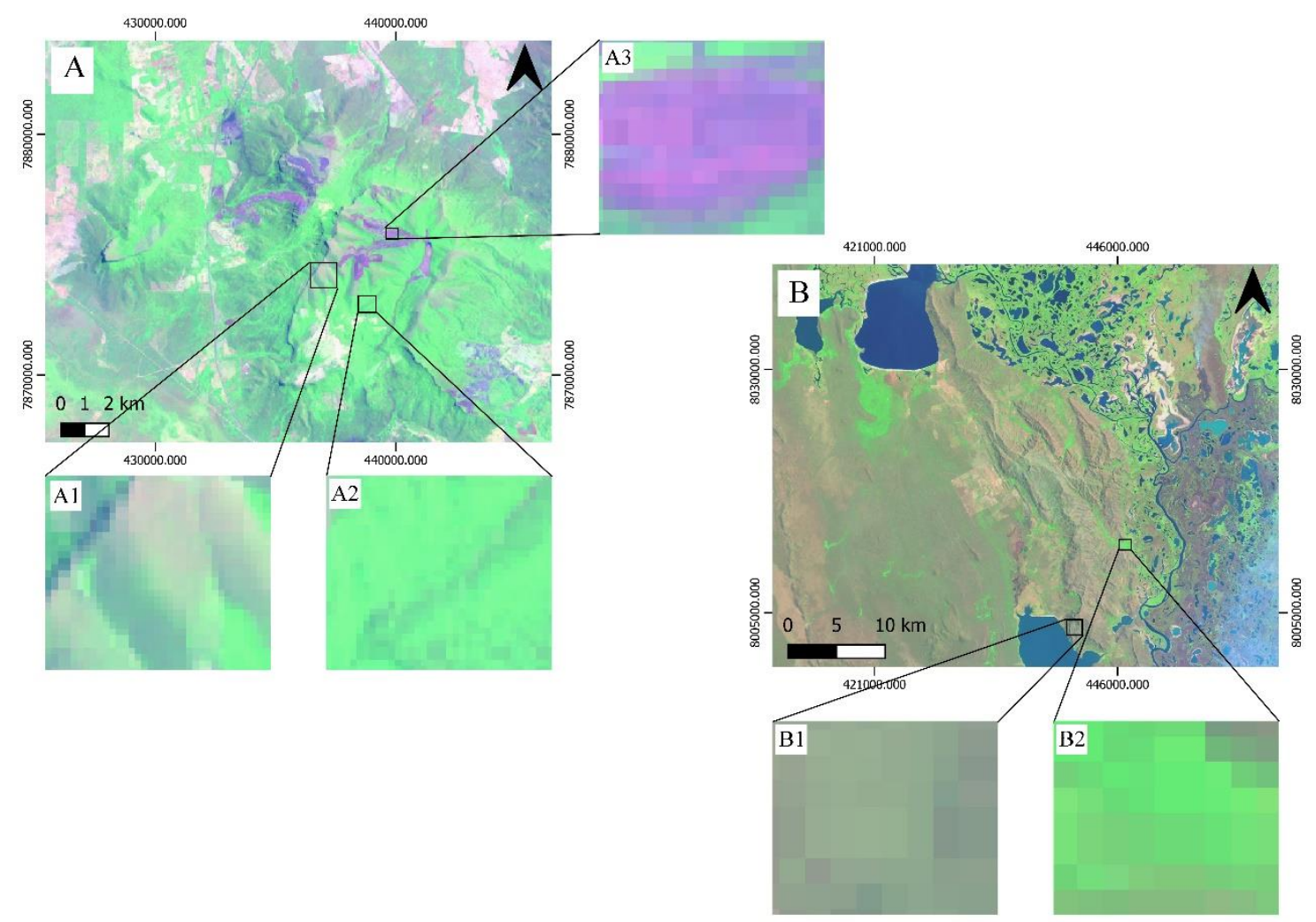

Source: Images from Landsat 8 (U.S. Department of the Interior U.S. Geological Survey, 2020).

After defining the vegetation classes, cuts were made from sample areas (Figure 4) of grassy vegetation classes (Campos de Altitude), arboreal, and exposed soil using the polygon tool in QGIS 3.10, to be superimposed on the NDVI product (1985 and 2020). The goal was to determine the index's maximum and minimum values, as well as which value ranges each class would fall into. Although NDVI values can range from -1 to 1 , in finished products downloaded from Landsat 5 and 8, the values are distributed with a multiplier factor of 20,000 for Landsat 5 and 10,000 for Landsat 8. Therefore, such values were used in the current study to facilitate the visualization and discussion of results. Table 2 displays the minimum and maximum NDVI values. 
Figure 4 - Sample areas cut for defining vegetation classes. A corresponds to Campos de Altitude (red polygons), exposed soil (orange polygons), and arboreal vegetation (green polygons) in the Morraria do Urucum study area; B correspond to Campos de Altitude (grey polygons) and arboreal vegetation (green polygons) in the Serra do Amolar study area.
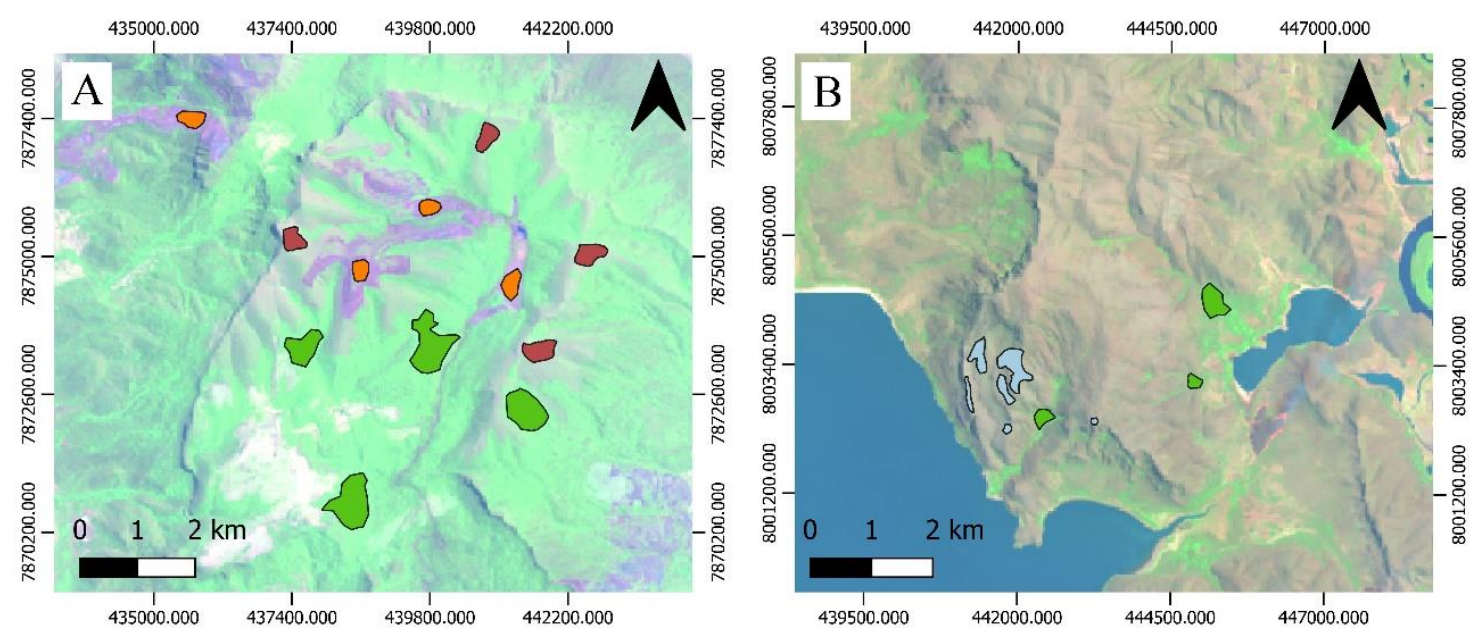

Source: Images from Landsat 8 (U.S. Department of the Interior U.S. Geological Survey, 2020).

Table 2 - NDVI product minimum and maximum scale information values from Landsat 5 and Landsat 8 images.

\begin{tabular}{cccc}
\hline Area & Year & Minimum value & Maximum value \\
\hline Morraria do & 1985 & -10000 & 20000 \\
Urucum & 2020 & -4360 & 10000 \\
Serra do & 1985 & -3486 & 20000 \\
Amolar & 2020 & -5250 & 10000 \\
\hline
\end{tabular}

Source: Authors.

The presence of exposed soil due to mining activities stands out in Morraria do Urucum. The company Urucum Mineração, which was later acquired by CVRD, has been conducting mining activities in Morraria since the mid-1970s (Brito 2011). As a result, the exposed soil class was also measured, and the total area of the class measured in the 1985 NDVI (areas where mining activity had not yet occurred) was subtracted from the 2020 NDVI (areas with exposed soil but no post-mining vegetation), so that the class was not overestimated in those locations. Following the determination of maximum and minimum NDVI values for the analyzed classes, the NDVI product was reclassified on QGIS 3.10 using the r.recode tool for the defined intervals, resulting in a product of clustered pixels. The data was then converted from raster to polygon and the of each class areas (in hectares) were calculated using the field calculator. This allowed for the quantification of pixels in terms of area. Because this process was carried out for the two NDVI products from both years of analysis (1985 and 2020), the difference in coverage of the classes (in area) could be calculated to verify variations between these years.

Morraria do Urucum also has pasture areas. These areas were manually classified by polygons as the NDVI values are similar to the NDVI values of Campos de Altitude, because it is of grass type and the NDVI ranges are similar or close. In this case, the pasture was classified as Campos de Altitude, and it was subtracted from the total Campos de Altitude area after being manually selected. It is worth noting that this area was classified due to the presence of Campos de Altitude in this location in 1985 (Figure 5). 
Figure 5 - Area with pasture in Morraria do Urucum in the 2020 scene. In A, pasture in the RGB false-color image. In B, NDVI product with delimited pasture, where the NDVI scale values resemble those of Campos de Altitude.
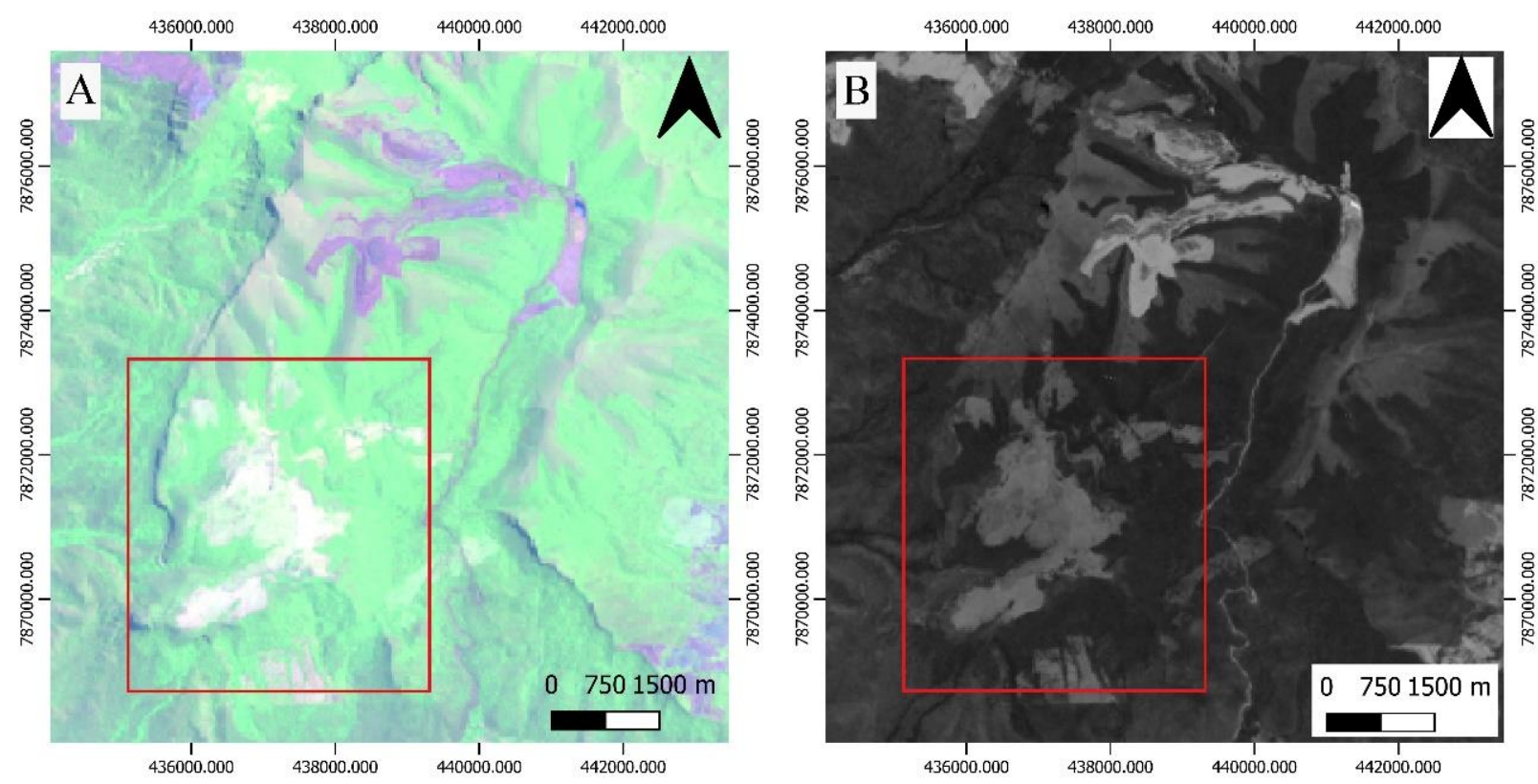

Source: Images from Landsat 8 (U.S. Department of the Interior U.S. Geological Survey, 2020).

\subsection{Delimitation of the Morraria do Urucum and Serra do Amolar areas}

To avoid errors in classifying the classes and overestimating the pixels of NDVI maps (1985-2020) that were not within the area of interest, particularly the Campos de Altitude class, which can be confused with other NDVI pixels, the two study areas were delimited using a QGIS 3.10 procedure. The altimetry data (TOPODATA 2008) of the study areas (available on the INPE website at: http://www.webmapit.com.br/inpe/topodata/) were reclassified to values greater than 400 meters, since from this attitude the entire area of interest for this study was expressed, containing the highest parts with the presence of the Campos de Altitude, which was the area with vegetation that interested us in the analysis. Following reclassification, the raster was converted into a shapefile (Figure 6).

Figure 6 - Polygons generated from altimetry data in both study areas. In A, Morraria do Urucum; in B, Serra do Amolar.
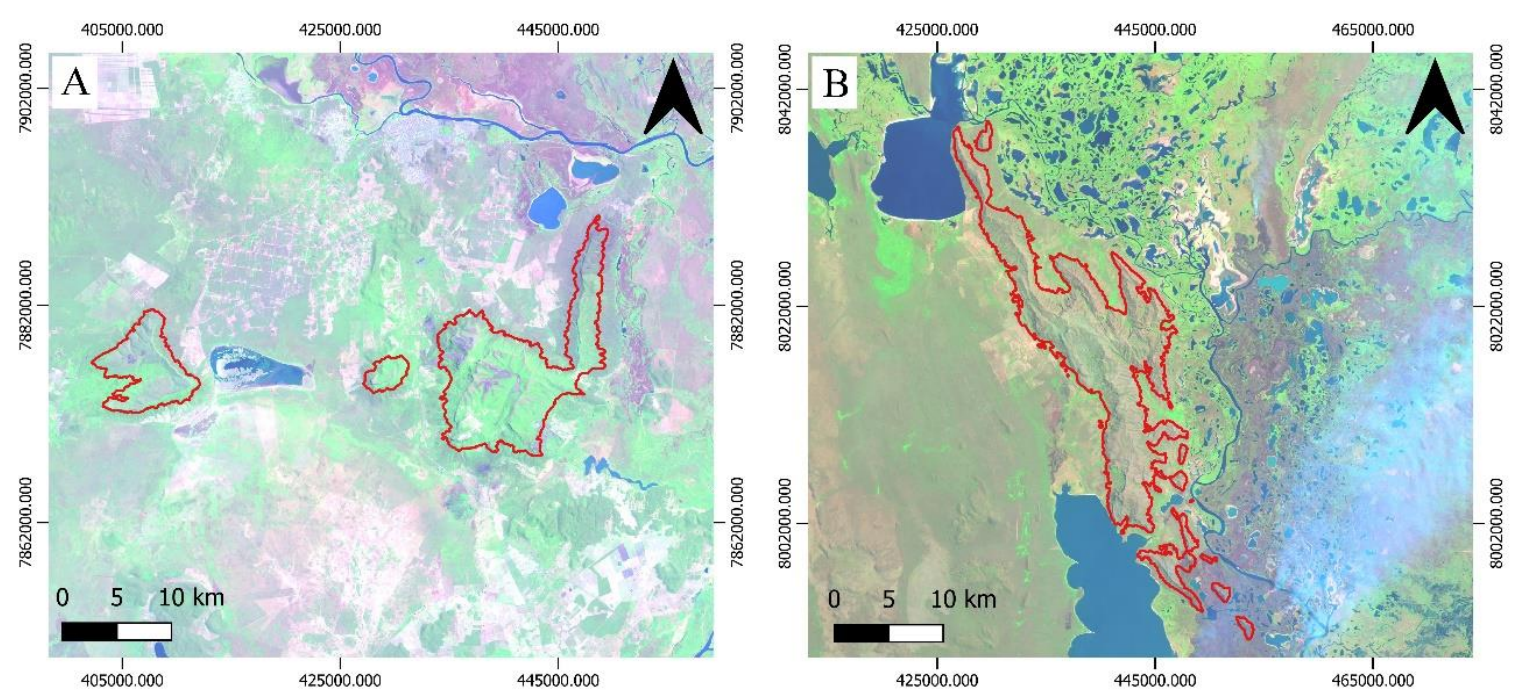

Source: Images from Landsat 8 (U.S. Department of the Interior U.S. Geological Survey, 2020). 


\subsection{Multi-temporal false color composition}

A multi-temporal false-color composition was created by changing the Red channel with the NDVI 1985 product, the Green channel with the NDVI 2020 product. This composition was used to visually validate the findings of the temporal variation analysis in the Campos de Altitude area. This occurred because the areas that underwent some change in vegetation, whether in phytomass or where the vegetation was replaced by another type of phytophysiognomy or land cover, present a red color in the image. Green areas correspond to an increase in phytomass or the presence of another type of more robust vegetation. Unmodified sites are represented in yellow.

\section{Results and Discussion}

Table 3 shows the minimum and maximum NDVI values for the two areas during both periods.

Table 3 - Minimum and maximum NDVI values found for Campos de Altitude in both areas and years analyzed.

\begin{tabular}{|c|c|c|c|c|}
\hline Area & Vegetation & Year & Minimum Value & Maximum Value \\
\hline \multirow{6}{*}{$\begin{array}{c}\text { Morraria do } \\
\text { Urucum }\end{array}$} & \multirow{2}{*}{ Campos de Altitude } & 1985 & 947 & 3243 \\
\hline & & 2020 & 4508 & 6927 \\
\hline & \multirow{2}{*}{ Arboreal vegetation } & 1985 & 3525 & 4826 \\
\hline & & 2020 & 7172 & 8366 \\
\hline & \multirow{2}{*}{ Exposed Soil } & 1985 & - & - \\
\hline & & 2020 & 1192 & 4414 \\
\hline \multirow{4}{*}{ Serra do Amolar } & \multirow{2}{*}{ Campos de Altitude } & 1985 & 947 & 3643 \\
\hline & & 2020 & 2531 & 4011 \\
\hline & \multirow{2}{*}{ Arboreal vegetation } & 1985 & 3643 & 5316 \\
\hline & & 2020 & 4011 & 7589 \\
\hline
\end{tabular}

Source: Authors.

As shown in table 3, the minimum and maximum values of the NDVI spectral scale are different for different land cover classes, and also for different sensors (OLI and TM). Classes with bare soil and undergrowth (Campos de Altitude) are lower when compared to arboreal vegetation, and values tend to increase as vegetation becomes more robust. Therefore, because of this difference in value scales for the different classes, it was possible to identify and differentiate the classes analyzed in this study. This same pattern of values for classes and for different sensors was observed in the study by Peres et al. (2016), where the same land cover analysis method was used. Figure 7 and Figure 8 depicts the NDVI product of both study areas, with darker shades (dark gray) indicating areas with higher plant biomass, lighter shades (light gray) indicating grassy vegetation (Campos de Altitude), and white tones indicating areas without vegetation (exposed soil). 
Figure 7 - NDVI product images of the analysis areas with the maximum and minimum NDVI values as shown in Table 3. In A and B, Serra do Amolar in 2020 and 1985, respectively.

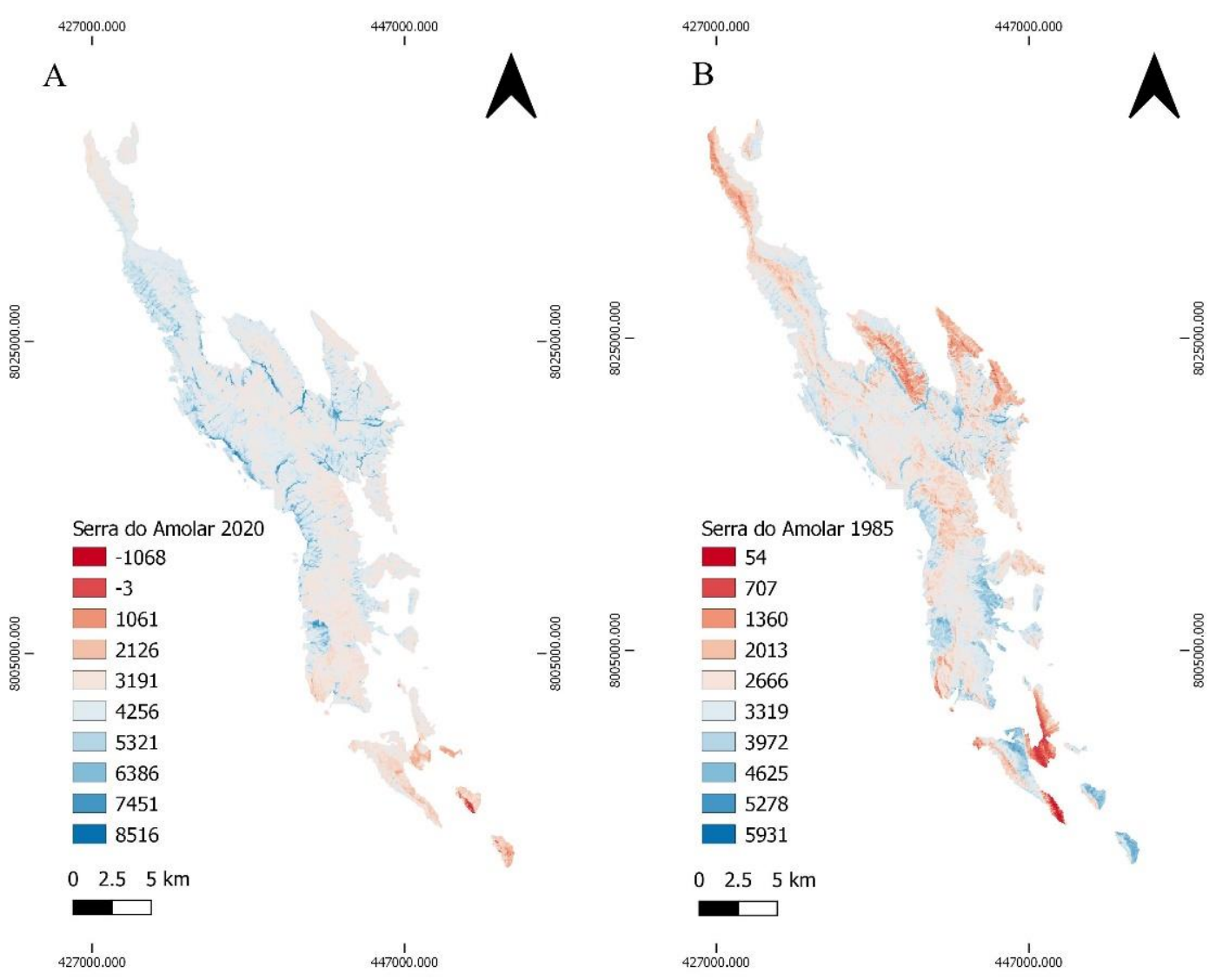

Source: Authors. 
Figure 8 - NDVI product images of the analysis areas with the maximum and minimum NDVI values as shown in Table 3 . In C and D, Morraria do Urucum in 2020 and 1985, respectively.

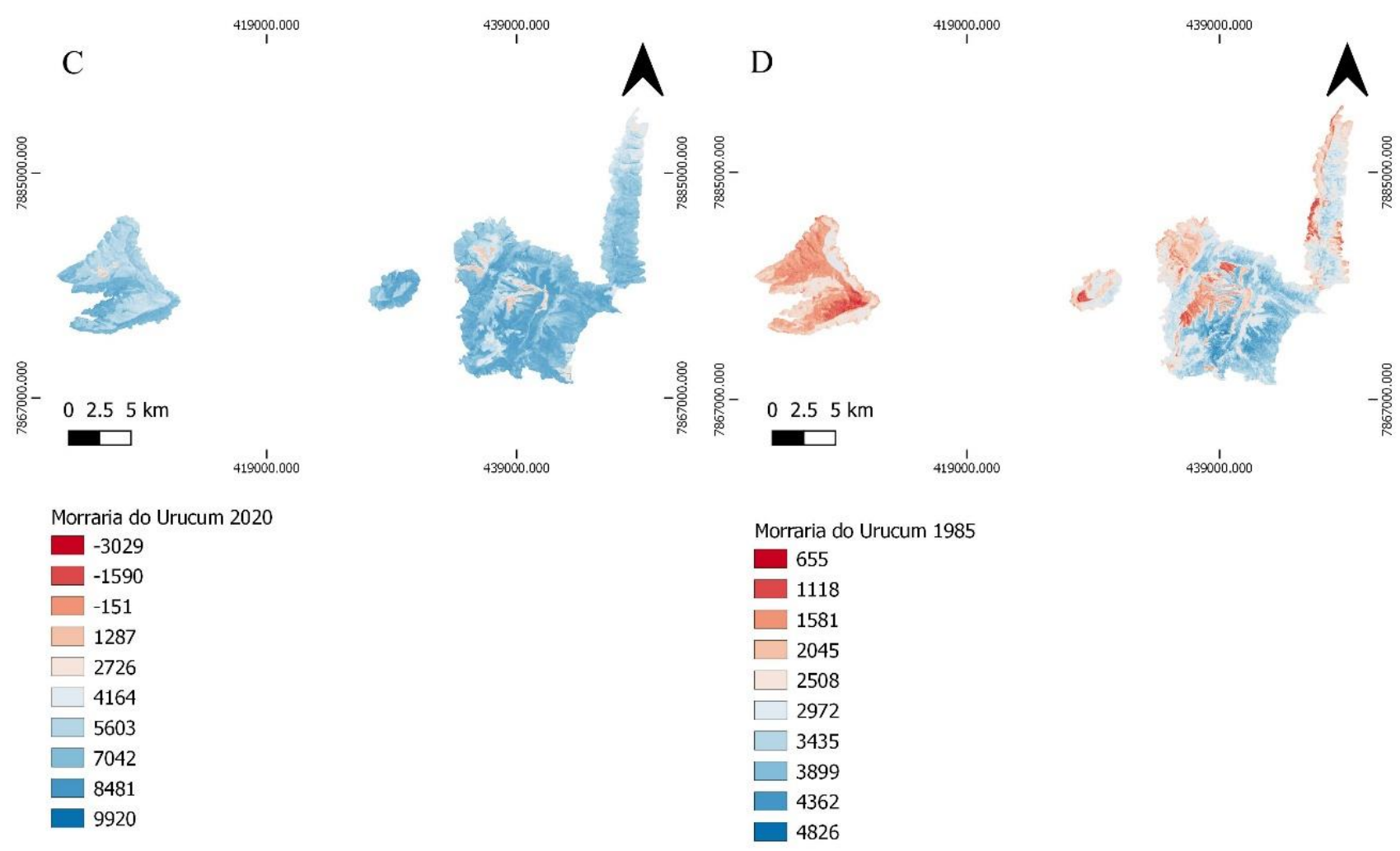

Source: Authors.

The color gradient in Figure 7, corresponding to the values by land cover class is illustrated, as shown in Table 3. For the Serra do Amolar area, in Figure 7A (2020) the values between 2500 and 4000 are illustrated in the higher regions of the Serra do Amolar (above 500 meters, see Figure 1). In these regions are the Campos de Altitude. The same is seen in Figure 7B (1985), but with the scale of different values, between 950 and 3650. The same happens for the Morraria do Urucum area, in Figures 7C and 7D, where the scales of values from 4500 to 6950 in image 7C (2020) refer to Campos de Altitude. And for the 7D image (1985), the values from 950 to 3250 are related to the Campos de Altitude land cover class.

Table 4 describes the total area quantified for each class as well as the comparison between the years of analysis (1985-2020). The negative values reflect a decrease in the respective classes, while the positive values reflect an increase in the respective classes. 
Table 4 - Spatiotemporal distribution for the analyzed classes and the differences in area between the studied years.

\begin{tabular}{|c|c|c|c|c|c|}
\hline Area & Class & Year & Area (ha) & Difference (ha) & Percentage \\
\hline \multirow{8}{*}{$\begin{array}{c}\text { Morraria do } \\
\text { Urucum }\end{array}$} & \multirow{2}{*}{ Campos de Altitude } & 1985 & 6.207 & \multirow{2}{*}{-1.982} & \multirow{2}{*}{-31.93} \\
\hline & & 2020 & 4.225 & & \\
\hline & \multirow{2}{*}{ Arboreal } & 1985 & 4.109 & \multirow{2}{*}{1.267} & \multirow{2}{*}{30.83} \\
\hline & & 2020 & 5.376 & & \\
\hline & \multirow{2}{*}{ Exposed Soil } & 1985 & - & \multirow{2}{*}{-} & \multirow{2}{*}{-} \\
\hline & & 2020 & 612 & & \\
\hline & \multirow{2}{*}{ Pasture } & 1985 & - & \multirow{2}{*}{-} & \multirow{2}{*}{-} \\
\hline & & 2020 & 420 & & \\
\hline \multirow{4}{*}{$\begin{array}{l}\text { Serra do } \\
\text { Amolar }\end{array}$} & \multirow{2}{*}{ Campos de Altitude } & 1985 & 18.911 & \multirow{2}{*}{-6.642} & \multirow{2}{*}{-35.12} \\
\hline & & 2020 & 12.269 & & \\
\hline & \multirow{2}{*}{ Arboreal } & 1985 & 2.790 & \multirow{2}{*}{6.411} & \multirow{2}{*}{230} \\
\hline & & 2020 & 9.201 & & \\
\hline
\end{tabular}

Source: Authors.

Between 1985 and 2020, the Campos de Altitude area decreased in both study areas, decreasing by $31.93 \%$ in Morraria do Urucum and 35.12\% in Serra do Amolar. The opposite was observed in the denser strata (arboreal) vegetation, which increased in spatial distribution in both areas, with an exceptional 230\% increase in Serra do Amolar.

The degradation of Campos de Altitude in Morraria do Urucum is primarily linked to the expansion of human activities, as this area contains mining operations by company Vale do Rio Doce and a small area with pasture for cattle raising. These two activities combined reduced the Campos de Altitude area by $52.1 \%$.

The remaining $47.9 \%$ reduction may be due to environmental factors, as the tree layer increased over the years of analysis and may have occupied the area where Campos de Altitude was present in 1985. The same effect was observed in Serra do Amolar, where Campos de Altitude reduced by 35.12\% (6,642 ha), a value that was very close to the increase in dense vegetation (arboreal), which was 6411 ha.

In order to evaluate in more detail the evolution of the loss of altitude field area and increase in dense vegetation areas (trees), a multitemporal composition was carried out, which illustrates well the areas where reduction (colors in red), increase occurred (colors in green) and areas that showed no difference (colors in yellow) in plant biomass (Figure 8 and Figure 9). 
Figure 8 - Multi-temporal composition of NDVI products from the analysis years. In A, Morraria do Urucum; in B, Serra do Amolar. Caption: Green - plant biomass gain; Red - loss of plant biomass; Yellow - unchanged.

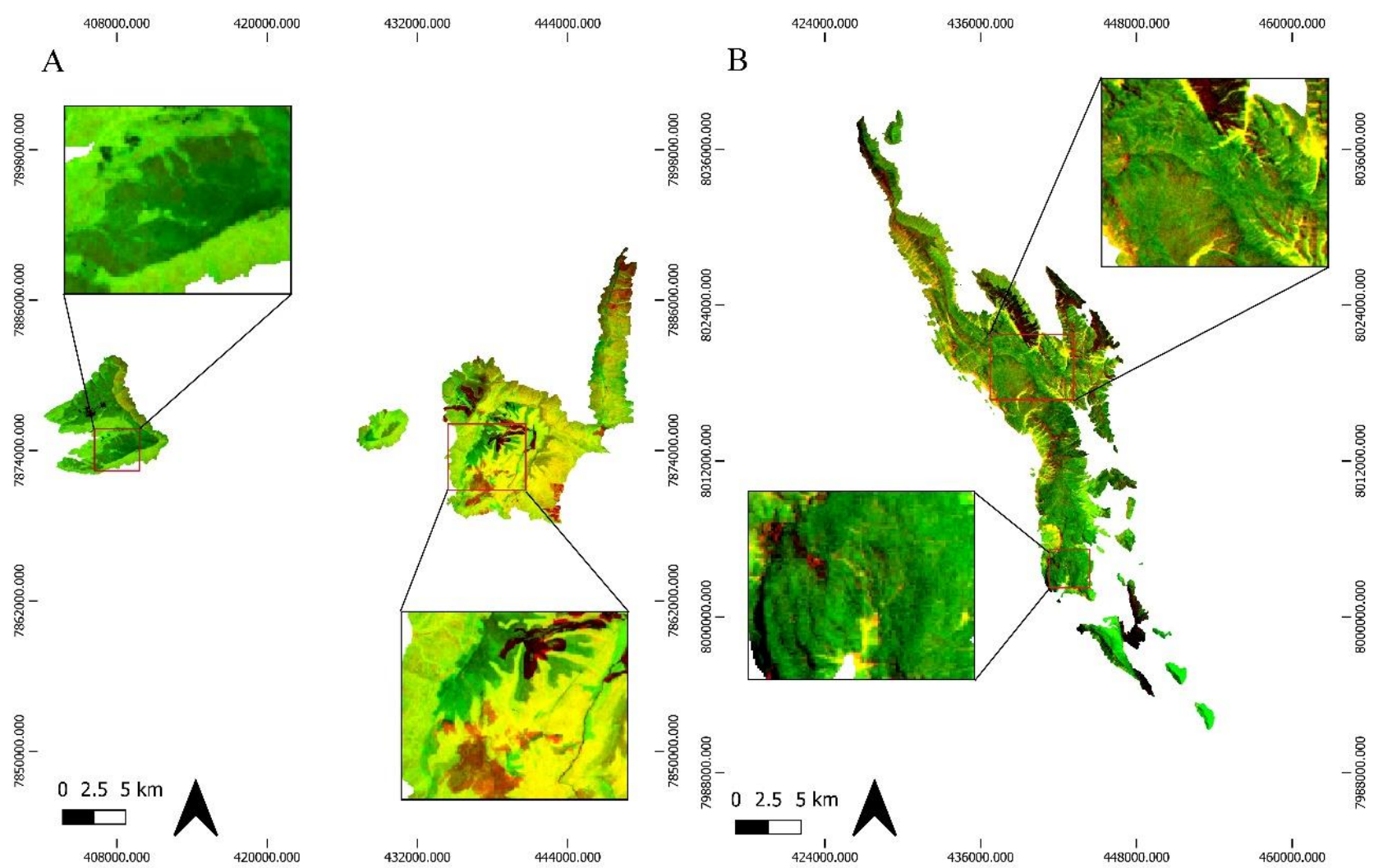

Source: Authors. 
Figure 9 - Area cut for comparison between the NDVI products from 1985 and 2020. In: A1 and B1, Multi-temporal composition, A2 and B2, Morraria do Urucum 1985, A3 and B3, Morraria do Urucum 2020; C1, Multi-temporal composition, C2, Serra do Amolar 1985, and C3, Serra do Amolar 2020.
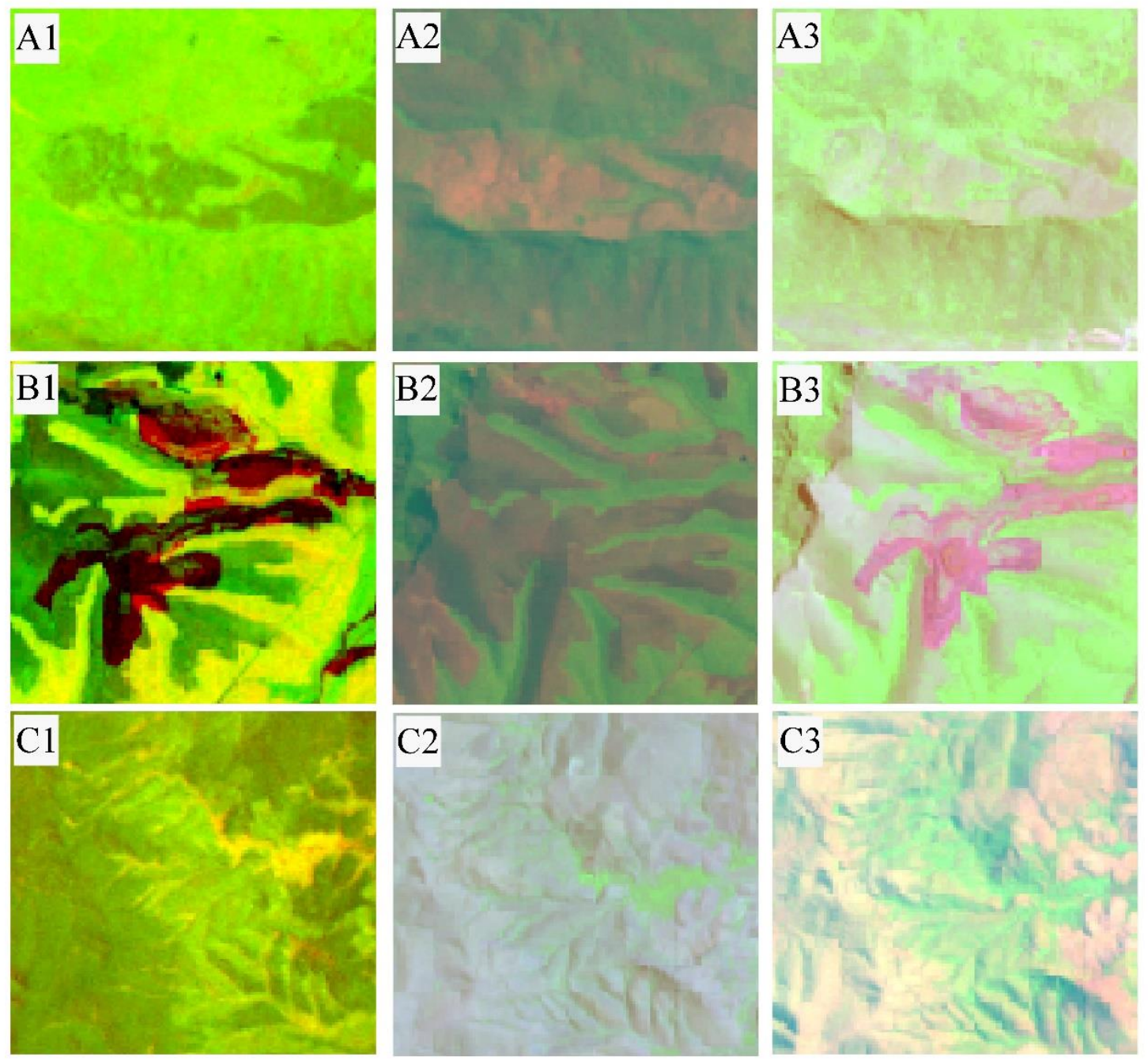

Source: Authors.

Plant biomass increased in both areas, most notably in Serra do Amolar (Figure 8b) and in some areas of Morraria do Urucum (Figure 8a). The greater the gain in plant biomass, the darker the color on the green scale. This also holds true for the red scale, which can be found in Morraria do Urucum's pasture and mining areas. In areas with shades of yellow there was no significant difference in plant biomass between the years analyzed.

In summary, the higher areas (above $700 \mathrm{~m}$ ) with Campos de Altitude vegetation gradually increased their plant biomass, which was caused, on the one hand, by the advancement of dense vegetation and (arboreal), on the other, by the possibility that Campos de Altitude suffered an increase in plant density, reflecting a different spectral response and, as a result, also different NDVI values.

Zhang et al. (2007) investigated the relationship between NDVI and climatic variables and observed that the growth of alpine vegetation reflected an increase in NDVI, with precipitation being attributed to the observed fluctuations in NDVI, and that high potential evaporation can have a negative impact on the growth of alpine vegetation, causing it to be replaced by other denser vegetation. Zeng et al. (2019) estimated the aboveground plant biomass (AGB, above ground biomass) of pastures (alpine vegetation) in the Tibetan Plateau from 2000 to 2014 using vegetation indices and meteorological variables. The 
authors observed an obvious spatial heterogeneity and an increasing trend in plant biomass growth as a reflection of environmental (meteorological) variables, and they concluded that the spatial distribution of AGB grassland is sensitive to precipitation, while the AGB temporal dynamics were significantly correlated with temperature.

Changes in plant biomass are more visible in Figure 8, which contrasts the multitemporal false-color composition with the two years of analysis. Figures A1-A3 (Morraria do Urucum) show that Campos de Altitude has shrunk in size and that arboreal vegetation has expanded. Figures C1-C3 depict the same phenomenon for Serra do Amolar. Figures B1-B3 depict the suppression of vegetation (red to dark red tones) caused by mining activities in Morraria do Urucum. However, Serra do Amolar is a complex of Conservation Units and RPPNs, and it is difficult to access (by boat or plane), making human activities harder to occur. Significant changes in climatic conditions, as well as ongoing human alteration through land use and other activities, undoubtedly have an impact on the world's natural grassland ecosystems (alpine vegetation), particularly in regions that are vulnerable to climate change, such as alpine regions (Beniston 2003; Zhang et al. 2007)

This study approaches the unequal spatiotemporal alterations of Campos de Altitude, as well as certain relationships between the potential driving forces associated with this phenomenon. Nevertheless, further in-depth research is required to identify possible environmental causes related to space-time changes in Campos de Altitude areas where no human activity occurred, both in Morraria do Urucum and Serra do Amolar. The results presented here only describe a portion of the complex dynamics of Campos de Altitude as they relate to environmental factors and possible anthropogenic mechanisms (mining activity) that are responsible for the alteration of Campos de Altitude dynamics and degradation in this region.

Using Landsat images, this study examined the changes in alpine vegetation cover (Campos de Altitude) between 1985 and 2020. During the years studied, there was a noticeable increase in arboreal vegetation in both study areas. The tendency for the fraction of arboreal vegetation cover to increase is in line with the decrease in Campos de Altitude vegetation, and this phenomenon can be attributed to environmental factors such as temperature, rainfall, solar radiation, and physicalchemical changes in the soil. The main factor for the increase in arboreal vegetation cover, as observed in other studies (Zhou et al. 2016; Bai et al. 2020; Zhang et al. 2007; Li \& Qu 2018; Ma et al. 2019; Shen et al. 2015), is an increase in temperature and precipitation. In Morraria do Urucum, the decrease in Campos de Altitude is linked to anthropogenic pressures such as mining activities and cattle grazing.

\section{Conclusion}

This research approached the distribution of vegetation cover in two mountainous areas of Mato Grosso do Sul. Although the anthropogenic influence on land cover changes in Morraria do Urucum was observed, the spatiotemporal variation relationship of Campos de Altitude in areas where there was no anthropogenic pressure, both in Morraria do Urucum and in Serra do Amolar, has yet to be explained. Nevertheless, the results showed that there was clearly a difference between the years of study; therefore, further research is required to understand the environmental factors that led to this difference in vegetation cover, as well as the dynamics of such factors, so as to better contemplate the Campos de Altitude vegetation, which is an important ecosystem of Pantanal, and to determine whether climate change has an impact in this region.

For future research, we intend to use the same study areas, however seeking to understand which environmental factors led to differences in the coverage and distribution of Campos de Altitude. We also aim to automate this method for a more refined/accurate classification that is automatic without intervention in land cover classification. The research carried out in this study can be expanded and replicated to other study areas that are not necessarily the Pantanal biome, since the Campos de Altitude are not restricted to this biome, and can also be used for other types of vegetation that belong to the same class than the Campos de Altitude (grasses). 


\section{Acknowledgments}

The authors would like to express their gratitude to the Graduate Program in Environmental Management and Technology (PGTA), at the Federal University of Mato Grosso do Sul (UFMS).

This study was carried out with the support of the Federal University of Mato Grosso do Sul - UFMT/MEC - Brazil.

To CNPq for the financial support (Processes 441975/2018-6 - Prev-fogo Public Notice and 315170/2018-2 - DT and EI Productivity Grant); To the Public Ministry of MT, for the financial support (Prorad Project) and Federal University of Rondonópolis - UFR, for the logistical and financial support.

The research was also made possible by the Coordenação de Aperfeiçoamento de Pessoal de Nível Superior (CAPES), Brazil, for the financial support needed to carry out this research. Financing Code 001 and Conselho Nacional de Desenvolvimento Científico e Tecnológico (CNPq) (Processes 441975/2018-6, 305013/2018-1, 315170/2018-2 and 307429/2019-9).

We also thank CAPES for providing us with access to the Journals Portal. We would also like to thank CAPES for the doctoral scholarship granted to Dhonatan Diego Pessi (process number 88887.494036/2020-00).

\section{References}

Bai, Y. et al. (2020). Climate warming benefits alpine vegetation growth in Three-River Headwater Region, China. Science of the Total Environment, 742: 110 .

Berberoglu, S. et al. (2011). Mapping and monitoring of coastal wetlands of Cukurova Delta in the Eastern Mediterranean region. Biodivers. Conserv, 13: $615-633$

Brito, N. de M. (2011). Desenvolvimento econômico e mineração: uma abordagem da atividade em Corumbá, MS. Entre-Lugar, 4: 123-150.

Beniston, M. (2003). Climatic change in mountain regions: a review of possible impacts. Clim. Change, 59: 5-31.

Brasil. (2008). Instituto Nacional de Pesquisas Espaciais (INPE). Topodata: banco de dados geomorfométricos do Brasil. Variáveis geomorfométricas locais. São José dos Campos, 2008. <http://www.dsr.inpe.br/topodata/>.

Chen, B. et al. (2018). Dynamic monitoring of the Poyang Lake wetland by integrating Landsat and MODIS observations. ISPRS J. Photogramm. Remote Sens, 139: 75-87.

Dronova, I. et al. 2012. Landscape analysis of wetland plant functional types: the effects of image segmentation scale, vegetation classes and classification methods. Remote Sens. Environ, 127: 357-369.

EMBRAPA. (2021). Empresa Brasileira de Pesquisa Agropecuária. LANDSAT - Land Remote Sensing Satellite. 2021. Disponível em: https://www.embrapa.br/satelites-de-monitoramento/missoes/landsat. Acesso em: 28 jan. 2021.

ECOTRÓPICA - Fundação de apoio à vida nos trópicos. 2003. Plano de Manejo das RPPN’S Acurizal, Penha e Dorochê. Cuiabá, Mato Grosso. 125p.

Foley, J.A. et al. (2005). Global consequences of land use. Science, 309: 570-574.

Guerra, A. et al. (2020). Drivers and projections of vegetation loss in the Pantanal and surrounding ecosystems. Land Use Policy, 91 : 104388.

Jeong, S. J. et al. (20110. Phenology shifts at start vs. end of growing season in temperate vegetation over the Northern Hemisphere for the period $1982-2008$. Glob. Chang. Biol, 17: 2385-2399.

Johnston, R. M. \& Barson, M. M. (1993). Remote sensing of Australian wetlands: an evaluation of Landsat TM data for inventory and classification. Mar. Freshw. Res., 44: 235-252.

Junk, W. J. et al. (2006). Biodiversity and its conservation in the Pantanal of Mato Grosso, Brazil. Aquat. Sci., 68: $278-309$.

Larcher, L.; Rabelo, A. \& Viana, D. F. P. (2017). Rede De Proteção E Conservação Da Serra Do Amolar: Um Modelo De Conservação Integrado. In: João Carlos Ferreira de Melo Júnior; Therezinha Maria Novais de Oliveira. (Org.). Ciências ambientais: ensaios e perspectivas. 1ed. Joinville: Univille, v. 1, 225240 .

Han, X. et al. (2015). Four decades of winter wetland changes in Poyang Lake based on Landsat observations between 1973 and 2013. Remote Sens. Environ., 156: $426-437$.

IHP - Instituto Homem Pantaneiro. 2012. Descobrindo o Paraíso: aspectos biológicos da reserva particular do patrimônio natural engenheiro Eliezer Batista - RPPN EEB/ Pantanal Sul. Org. Rabelo, A. C. P.; Moreira, V. F.; Bertassoni, A.; AOKI, C. Rio de Janeiro, RJ. 111 p. 
LANDSAT. (2020). Imagem Landsat 8 OLI. Canais 1, 2, 3, 4, 5, 6, 7, 8, 9, 10, 11 e NDVI. Landsat-8 image courtesy of the U.S. Geological Survey. Imagem de Satélite. Órbita 227 ponto 073. De 28 de setembro de 2020. 2020.

LANDSAT. (2020). Imagem Landsat 8 OLI. Canais 1, 2, 3, 4, 5, 6, 7, 8, 9, 10, 11 e NDVI. Landsat-8 image courtesy of the U.S. Geological Survey. Imagem de Satélite. Órbita 227 ponto 072. De 28 de setembro de 2020. 2020.

LANDSAT. (1985). Imagem Landsat 5 TM. Canais 1, 2, 3, 4, 5, 6, 7 e NDVI. Landsat-5 image courtesy of the U.S. Geological Survey. Imagem de Satélite. Órbita 227 ponto 073. De 12 de setembro de 1985. 1985.

LANDSAT. (1985). Imagem Landsat 5 TM. Canais 1, 2, 3, 4, 5, 6, 7 e NDVI. Landsat-5 image courtesy of the U.S. Geological Survey. Imagem de Satélite. Órbita 227 ponto 072. De 27 de agosto de 1985. 1985.

Li, X. \& Qu, Y. (2018). Evaluation of Vegetation Responses to Climatic Factors and Global Vegetation Trends using GLASS LAI from 1982 to 2010. Canadian Journal Of Remote Sensing, 44: 357-372.

Linscheid, N. et al. (2020). Towards a global understanding of vegetation-climate dynamics at multiple time scales. Biogeosciences, 17: 945-962.

Ma, X. et al. (2019). Sensitivity of Vegetation on Alpine and Subalpine Timberline in Qinling Mountains to Temperature Change. Forests, 10: 1-16.

Marengo, J. M. et al. (2021). Extreme Drought in the Brazilian Pantanal in 2019-2020: Characterization, Causes, and Impacts. Frontiers in Water, 3: 639204.

Mioto, C.L. et al. (2012). Contribuição à caracterização das sub-regiões do Pantanal. Rev Entre-Lugar, 3:165-180.

Um, S. et al. (2020). Monitoring the spatio-temporal dynamics of the wetland vegetation in Poyang Lake by Landsat and MODIS observations. Science of the Total Environment, 725: 138096.

Newbold, T. (2018). Future effects of climate and land-use change on terrestrial vertebrate community diversity under different scenarios. Proc. R. Soc. B Biol. Sci., 285: 20180792.

Pan, N. et al. (2018). Increasing global vegetation browning hidden in overall vegetation greening: Insights from time-varying trends. Remote Sensing of Environment, 214: 59-72.

Peres, P.N. et al. (2016). Variação da Cobertura do Solo no Pantanal de 2000 a 2015 por Sensoriamento Remoto com Software e Dados Gratuitos. Anuário do Instituto de Geociências - UFRJ, 39: 116-123.

Pouliot, D. et al. (2009). Trends in vegetation NDVI from $1 \mathrm{~km}$ AVHRR data over Canada for the period 1985-2006. International Journal of Remote Sensing, 30: 149-168.

Pott, A. et al. (2011). Plant diversity of the Pantanal wetland. Brazilian Journal of Biology, 71: 265-273.

Pott, A. et al. (2000). Vegetação e uso da terra. p.111-131. In: SILVA J. S. V. (ed.). Zoneamento ambiental da borda oeste do Pantanal: Morraria do Urucum e adjacências. Embrapa Informação e Tecnologia, Brasília, DF. 365p.

QGIS Development Team, (2021). QGIS Geographic Information System. Open Source Geospatial Foundation Project. http://qgis.osgeo.org.

Roque, F. O. et al. (2016). Upland habitat loss as a threat to Pantanal wetlands. Conserv. Biol., 30: 1131-1134.

Shen, M. et al. (2015). Plant phenological responses to climate change on the Tibetan Plateau: research status and challenges. National Science Review, 2: 454467.

Silva, J. S. V. \& Abdon, M. M. (1998). Delimitação do Pantanal Brasileiro e Suas Sub-regiões. Pesq. agropec. bras., 33: 1703-1711.

Souza, C. A. \& Souza, J. B. (2010). Pantanal Mato-grossense: origem, evolução e as características atuais. Revista Eletrônica da Associação dos Geógrafos Brasileiros, 11: 34-54.

SOS-Pantanal, WWF-Brasil, Conservation-International, ECOA, Fundacion-AVINA. (2017). Monitoramento das alterações da cobertura vegetal e uso do solo na Bacia do Alto Paraguai Porção Brasileira-Período de analise: 2016 a 2017. Corumba. Embrapa Pantanal.

TOPODATA. (2008). Banco de dados geomorfométricos do Brasil. Variáveis geomorfométricas locais. São José dos Campos, 2008. http://www.webmapit.com.br/inpe/topodata/

Urbanetz, C. et al. (2012). Composição e Distribuição de Espécies Arbóreas em Gradiente Altitudinal, Morraria do Urucum, Brasil. Oecol. Aust., 16: 859-877.

Wamelink, W. et al. (2018). The role of abiotic soil parameters as a factor in the success of invasive plant species. Emerging Sci. J., 2: 308-365.

Wang, X. et al. (2014). Alpine Cold Vegetation Response to Climate Change in the Western Nyainqentanglha Range in 1972-2009. The Scientific World Journal, 2014: 1-9.

Zhang, R. et al. (2019). Grassland vegetation phenological variations and responses to climate change in the Xinjiang region, China. Quaternary International, 513: 56-65.

Zhang, J. et al. (2007). Evaluation of Grassland Dynamics in the Northern-Tibet Plateau of China Using Remote Sensing and Climate Data. Sensors, 7: 33123328 .

Zeng, N. et al. (2019). Estimating grassland aboveground biomass on the Tibetan Plateau using a random forest algorithm. Ecological Indicators, 102: 479487.

Zhou, J. et al. (2016). Alpine vegetation phenology dynamic over 16 yers and its covariation with climate in a semi-arid region of China. Science of the Total Environment, 572: 119-128. 